H. Akhmad Dani dan Johansyah, Implikasi Penghapusan Desa Terhadap Kesejahteraan Masyarakat Desa, Halaman 118-134

\title{
IMPLIKASI PENGHAPUSAN DESA TERHADAP KESEJAHTERAAN MASYARAKAT DESA
}

\author{
H. Akhmad Dani ${ }^{1}$ dan Johansyah ${ }^{2}$ \\ ${ }^{1}$ Fakultas Hukum Universitas Palembang \\ E-mail: daniakhmadUnpal@yahoo.com \\ ${ }^{2}$ Fakultas Hukum Universitas Palembang \\ E-mail: Johanuh30@gmail.com
}

\begin{abstract}
The discourse on the abolition of the village has given birth to legal implications that are inconsistent with the values of certainty, justice, and usefulness that will be achieved in the purpose of structuring the village so that it has an impact on the continuation of the welfare of the village community. This is reflected in the management of village income and VillageOwned Enterprises which result in a legal vacuum after the abolition of the village so that the achievement of village community welfare will be hampered as mandated by the constitution in the Preamble to the 1945 Constitution of the Republic of Indonesia. Implications for the abolition of villages are included in village planning as regulated in statutory regulations Number 6 of 2014 concerning Villages. There is a clause on the purpose of village structuring which becomes a legal rule that should be carried out (das sollen) but there is a discrepancy when the legal rule is faced with the abolition of the village (das sein) because the abolition of the village has eliminated all provisions for the purpose of village structuring, so that villages that experience abolition in ultimately not oriented towards the purpose of structuring the village. On the other hand, the subjective legal reasons for the elimination of villages have reduced the role of the village in the elimination of villages by policies caused by the central government, which should involve local and village governments.
\end{abstract}

Keywords: village deletion

\begin{abstract}
Abstrak
Wacana penghapusan desa telah melahirkan implikasi hukum yang tidak berkesesuaian dengan nilai kepastian, keadilan, serta kebergunaan yang akan dicapai dalam tujuan penataan desa sehingga berdampak didalam kelanjutan terhadap kesejahteraan masyarakat desa. Hal tersebut tercermin dalam pengelolaan pendapatan desa serta Badan Usaha Milik Desa yang mengakibatkan kekosongan hukum setelah penghapusan desa sehingga akan terhambatnya pencapaian kesejahteraan masyarakat didesa sebagaimana yang telah diamanatkan oleh konstitusi dalam Pembukaan Undang Undang Dasar Republik Indonesia Tahun 1945. Implikasi dalam Penghapusan desa termasuk dalam penataan desa sebagaimana yang telah diatur dalam peraturan perundang-undangan Nomor 6 Tahun 2014 tentang Desa. Terdapat klausul tujuan penataan desa yang menjadi suatu kaedah hukum yang seharusnya dilakukan (das sollen) akan tetapi terdapat ketidaksesuain ketika kaedah hukum tersebut dihadapkan dengan penghapusan desa (das sein) karena penghapusan desa telah menghilangkan seluruh ketentuan tujuan penataan desa, sehingga desa yang mengalami penghapusan pada akhirnya tidak berorientasi pada tujuan penataan desa tersebut. Disisi lain, alasan hukum penghapusan desa yang bersifat subjektif menjadikan peran desa dalam penghapusan desa tereduksi oleh kebijakan yang diakibatkan oleh pemerintahan pusat yang selayaknya dalam pengahapusan desa seharusnya melibatkan pemerintah daerah dan desa.
\end{abstract}

Kata Kunci: penghapusan desa 
H. Akhmad Dani dan Johansyah, Implikasi Penghapusan Desa Terhadap Kesejahteraan Masyarakat Desa, Halaman 118-134

\section{PENDAHULUAN}

Pada Hakekat Negara Indonesia yang didalamnya terkandung cita-cita negaranya, mengenai pembenaran adanya Negara Indonesia, maupun mengenai tujuan Negara Indonesia, ternyata semua itu sama dengan hakekat, pembenaran adanya, terbentuknya, dan tujuan dari desa-desa itu sendiri. Semua itu tentunya dalam lingkup yang jauh lebih besar dan dalam konstelasi yang lebih modern.

Pada saat desa terbentuk, maka Ketika itu desa digambarkan sebagai bagian dari Negara kesatuan Indonesia. Pencerminan sebagai negara yang berazaskan pada nilai-nilai dalam Pancasila merupakan cerminan perilaku dan modal sosial dari masyarakat pada tingkat terbawah, yang lebih dikenal dengan masyarakat pedesaan. ${ }^{1}$ ". dimana didalamnya terkandung sebuah cita-cita bangsanya, sebagai negara kesatuan yang terdiri dari wilayah/provinsi setiap provinsi ada kabupaten/kota dan didalam kabupaten/kota akan di isi oleh kelurahan dan desa-desa yang masing masing desa ada masyarakat yang

1 Rico Hermawan, Jurnal Desentralisasi Volume 17 Nomor 1, Pusat Kajian Desentralisasi dan Otonomi Daerah Lembaga Administrasi Negara: Jakarta. 2017:16 berperan didalam kegiatan pelaksanaan pembangunan agar terwujud masyarakat yang sejahtera sebagaimana telah diamanatkan dalam pembukaan konstitusi.

Sejalan dengan hal tersebut, keberadaan desa sebagai susunan asli telah memiliki makna bahwa desa memiliki kesatuan masyarakat hukum tersendiri yang telah terbangun sejak lama. Singkatnya desa diartikan sebagai organisasi masyarakat adat atau desa adat yang mempunyai dan mengelola hak asal-usul dan adat istiadat. Indonesia terlahir karena ia memiliki suatu nyawa, suatu asas akal, yang tumbuh dalam jiwa rakyat sebelumnya yang menjalani suatu kesatuan riwayat, yang membangkitkan persatuan karakter dan kehendak untuk hidup bersama dalam suatu wilayah Indonesia. ${ }^{2}$ Hal demikian membuat keberadaan desa memiliki Kedudukan yang sama dalam Negara Kesatuan Republik Indonesia merupakan dua entitas yang tidak dapat dipisahkan satu sama lain. Menurut sifat tata negara Indonesia yang asli, yang sampai zaman sekarang pun masih dapat terlihat dalam suasana desa dimana

2 Yudi Latif, Negara Paripurna (Jakarta: Kompas Gramedia, 2017). 
H. Akhmad Dani dan Johansyah, Implikasi Penghapusan Desa Terhadap Kesejahteraan Masyarakat Desa, Halaman 118-134

para pejabat desa ataupun negara ialah pemimpin yang bersatu jiwa dengan rakyat dan para pejabat negara senantiasa wajib memegang teguh persatuan dan keseimbangan dalam masyarakatnya. Olehnya itu, dalam tataran aspek filosofis konseptual, Desa menjadi landasan dan bagian dari tata Kelola yang baik dalam pemerintahan, serta diharapkan desa menjadi penggerak dalam pembangunan sehingga manjadi harapan masyarakat desa agar tercapainya kemakmuran yang diharapkan oleh masyarakat setempat.

berbagai macam Keberagaman karakteristik dan jenis Desa, atau yang disebut dengan nama lain, tidak menjadi penghalang bagi para pendiri bangsa (founding fathers) ini untuk menjatuhkan pilihannya pada bentuk negara kesatuan. Meskipun disadari bahwa dalam suatu negara kesatuan perlu terdapat homogenitas, tetapi Negara Kesatuan Republik Indonesia tetap memberikan pengakuan dan jaminan terhadap keberadaan kesatuan masyarakat hukum dan kesatuan masyarakat hukum adat beserta hak tradisionalnya. ${ }^{3}$

\footnotetext{
3 Ni'Matul Huda, Hukum Pemerintahan Desa (Setara Press: Malang, 2015).
}

Desa Dalam bingkai Negara Kesatuan Republik Indonesia, pengakuan terhadap desa telah ada sejak awal kemerdekaan melalui Undang-Undang Nomor 1 Tahun 1945 tentang Peraturan Mengenai Kedudukan Komite Nasional Daerah yang mengakui kewenangan otonom Desa misalnya pada pemungutan pajak kendaraan dan rooiver gooningen. Sedangkan pengaturan desa secara konstitusional setelah amandemen. Termuat pada Pasal 18 UUD NRI Tahun 1945, ada dua norma dasar yang dapat dijadikan acuan dalam Pengaturan Desa, Pertama; norma dasar pemahaman konstitusi terhadap Desa dalam konteks pemerintahan daerah sebagaimana diatur dalam Pasal 18 ayat (7) kedua norma dasar pemahaman konstitusi terhadap Desa dalam konteks kesatuan masyarakat hukum adat sebagaimana diatur dalam Pasal 18B Undang Undang Dasar RI Tahun 1945.

Dalam poin Pasal tersebut diatas (Pasal 18 ayat 7), Pemerintahan Desa mempunyai satu kesatuan dengan pemerintahan daerah. Sedangkan dalam konteks Pasal 18B, makna kesatuan masyarakat hukum adat adalah Desa atau dengan sebutan lain 
H. Akhmad Dani dan Johansyah, Implikasi Penghapusan Desa Terhadap Kesejahteraan Masyarakat Desa, Halaman 118-134

yang beragam beserta hak-hak tradisionalnya. $^{4}$

Pada proses pembahasankedua pijakan yuridis konstitusional tersebut Pasal 18 ayat (7) dan Pasal 18 B ayat (2) mendapat tempat. Dalam penjelasan umum menyebutkan bahwa dalam kaitannya dengan susunan dan penyelenggaraan pemerintahan daerah setelah amandemen maka pengaturan desa atau dengan nama lain merujuk pada pasal 18 ayat (7) UUD NRI Tahun 1945 yang menegaskan, "Susunan dan tata cara penyelanggaraan pemerintahan daerah diatur dengan Undang-Undang”. Perumusan ini menjelaskan bahwa UUD NRI Tahun 1945 membuka kemungkinan adanya susunan pemerintahan dalam sistem pemerintahan Indonesia. Sedangkan pengakuan terhadap kesatuan masyarakat hukum adat dipertegas melalui ketentuan Pasal 18B ayat (2) UUD NRI Tahun 1945 yang berbunyi:

$$
\text { Negara mengakui dan }
$$
menghormati kesatuan-kesatuan masyarakat hukum adat beserta hakhak tradisionalnya sepanjang masih hidup dan sesuai dengan

\footnotetext{
${ }^{4}$ Muhammad Yasin Undang-Undang Nomor 6 Tahun 2014 Tentang Desa (Jakarta: Pusat Telaah dan Informasi Regional, 2015).
}

perkembangan masyarakat dan prinsip Negara Kesatuan Republik Indonesia, yang diatur dalam Undang-Undang.

Didalam Landasan konstitusional diatas telah menjadi dasar pengaturan terhadap desa yang kemudian melahirkan Peraturan Tentang Desa yang selanjutnya disebutdengan Undang-Undang Desa sebagaimana diatur dalam Undangundang Nomor 6 tahun 2014. Selanjutnya telah dirumuskan kedudukan Desa dalam rumusan Pasal 5 Undang-Undang Desa yang merupakan bagian dari kesepakatan atas usulan dalam pembahasan pembentukan peraturan desa, dan telah memposisikan desa yangberkedudukan dalam wilayah kabupaten/kota termasuk didalam negara kesatuan republik Indonesia.

Lahirnya peraturan tentang desa dimaksud telah melahirkan pengakuan terhadap keanekaragaman budaya yang timbul dan diakui oleh masyarakat desa, sedangkan terkait dengan relasi hubungan antara negara dengan desa setelah didudukkan, dimana negara tidak lagi mengontrol desa secara penuh tapi harus memposisikan desa itu sanggup mengelola dirinya sendiri. 
H. Akhmad Dani dan Johansyah, Implikasi Penghapusan Desa Terhadap Kesejahteraan Masyarakat Desa, Halaman 118-134

Konstruksi pemerintahan yang dianut dalam Undang-Undang Desa adalah konstruksi gabungan. Dengan demikian, asas asas yang dimuncukan dalam peraturan desa telah mengubah pendekatan kontrol atau pengendalian negara terhadap desa, dimana telah menempatkandesa sebagai subyek pembangunan dalam sistempemerintahan.

Maka jelas suatu hal yang tidak dapat diabaikan bahwa pandangan sebagian besar masyarakat terhadap peraturan yang mengatur Tentang Desa lebih tertuju kepada alokasi dana desa yang cukup besar. Sedangkan tujuan pokok aturan desa tidak hanya mengatur tentang keuangan desa tetapi telah mencakup seluruh kompleksifitas kebutuhan desa itu sendiri.

Salah satu pengaturan dalam Undang-Undang Desa adalah Penataan Desa. Upaya penataan desa merupakan suatu bentuk penghormatan yang asasi terhadap masyarakat desa serta kearifan dalam nilai-nilai lokal, penghargaan yang benar-benar penuh dengan penilaian terhadap kegiatan pemberdayaan dalam masyarakat desa. sedangkanPenataan desa menjadi suatu bentuk perhatian terhadap kepribadian lokal dan membentuktuntutan terus- menerus agar nilai-nilai masyarakat desa hendaknya jangan diabaikan tetapi dipahami dalam penataan desa. Pemerintah bagaimanapun harus mengembangkan kepekaan terhadap perbedaan-perbedaan, tujuan dan kebiasaan lokal.

Penataan desa sendiri memiliki tujuan yang termuat dalam UndangUndang Nomor 6 Tahun 2014 Tentang Desa bahwa " dalam penataan desa itu sendiri." Mewujudkan efektivitas penyelenggaraan Pemerintah Desa, Mempercepat peningkatan kesejahteraan masyarakat Desa, Mempercepat peningkatan kualitas pelayanan publik, Meningkatkan kualitas tata kelola Pemerintahan Desa dan Meningkatkan daya saing desa.

Pada Penataan desa terdiri atas beberapa bagian, salah satu bagian dari penataan desa adalah penghapusan desa. Penghapusan desa merupakan pencabutan status desa yang ada karena unsur wilayah dari desa tersebut telah hilang. Terdapat dua legal reasoning (alasan hukum) untuk dapat melakukan penghapusan desa yaitu akibat bencana alam dan/atau untuk kepentingan program nasional yang bersifat nasional 
H. Akhmad Dani dan Johansyah, Implikasi Penghapusan Desa Terhadap Kesejahteraan Masyarakat Desa, Halaman 118-134

Dimana dalam Tujuan hukum, penataan desa sebagaimana yang telah dikemukakan diatas, menjadi suatu kaedah hukum yang seyogyanya dilakukan, keseluruhan tujuan penataan desa diterapkan berdasarkan aturan maupun ketentuan yang diatur dalam undang-undang desa sehinggatentang apa yang seyogyanya tercipta. Namun, ketika kaedah hukum tersebut dihadapkan pada tataran realitas penghapusan desa (das sein), terdapat suatu ketidaksesuaian karena keseluruhan tujuan penataan desa hanya menjadi kaedah hukum yang bersifat pasif jika tujuan penataan desa tersebut dihadapkan dengan peristiwa hukum penghapusan desa yang menjadi bagian dari penataan desa. Ketidaksesuaian tersebut disebabkan karena penghapusan desa telah menafikkan ketentuan tujuan penataan desa, sehingga merugikan desa serta unsur dalam desa yang mengalami penghapusan yang tentunya bertolakbelakang dari tujuan yang dikehendaki.

Berkaitan dengan Implikasi hukum dari penghapusan desa, peraturan perundang-undangan terkait belum secara memadai dalam memberikan kepastian hukum bagi desa yang mengalami penghapusan termasuk masyarakat desa serta bergantung dari politik hukum pemerintah. Dalam realitas yang ada, tanggung jawab pemerintah hanya sebatas kompensasi secara personal. Pemberian Kompensasi semestinya tidak hanya terbatas pada ganti rugi secara individu melainkan Kompensasi yang diberikan semestinya dilakuan secara kolektif kepada seluruh wargadesa, misalnya dengan melalui berbagai program yang dimiliki pemerintah seperti pemberian lokasipenempatan pada tempatbaru untuk dijadikan sebagai desa peremajaan. Relokasi secara kolektif ini pada akhirnya akan tetap mempertahankan nilai nilai kearifan lokal dalam kesatuan masyarakat desa yang selama ini telahterjalin, termasuk mempertahankan budaya yang telah ada diantara mereka sebagai satu kesatuan masyarakat desa yang telah dijamin dalam konstitusi.

Ketidaksesuaian tujuan dari penataan desa dengan upaya pemerintah pusat dalam melakukan penghapusan desa yang menjadi bagian dari penataan desa akan berimplikasi terhadap kedudukan desa dan keberlangsungan kehidupan 
H. Akhmad Dani dan Johansyah, Implikasi Penghapusan Desa Terhadap Kesejahteraan Masyarakat Desa, Halaman 118-134

masyarakat desa beserta hak-haknya yang telah dijamin dalam konstitusi. Oleh karena itu penghapusan desa akan menentukan maju mundurnya pengaturan desa itu sendiri, yang berpengaruhdengan keutuhan dan kelangsungan dari nilai nilai budaya yang telah adadi desa juga berimbaskepada lenyapnya pemerintahan desa serta akan berpotensi menghilangkan entitas NKRI. Hingga pada akhirnya, rangkaian permasalahan diatas patut kemudian menjadi bahan kajian yang bersifat ilmiah dalam khasanah akademis mengenai analisis hukum terhadap penghapusan desa.

\section{PEMBAHASAN}

\section{A. Implikasi Hukum Terhadap Penghapusan Desa}

Pembahasan terhadap Implikasi hukum terhadap penghapusan desa berfokus pada kepastian hukum unsur desa setelah mengalami penghapusan serta pemenuhan hak hak desa.

$$
\text { Implikasi hukum dari }
$$
penghapusan desa terdiri ada beberapa aspek yaitu; 1) implikasi hukum terhadap masyarakat desa; 2) Implikasi hukum terhadap keuangan desa; 3) implikasi hukum terhadap badan usaha miliki desa yang akan dijelaskan secara menyeluruh pada pembahasan berikut ini.

\section{Implikasi hukum Terhadap}

\section{Masyarakat Desa}

Kalau merujuk dengan peraturan perundangan-undangan yang terkait penghapusan desa maka implikasi hukum yang ditimbulkan adalah tidak terakomodirnya hak kolektif dalam penghapusan desa, pemerintah hanya terfokus pemenuhan hak masyarakat desa secara personal tanpa adanya pemenuhan hak masyarakat desa secara kolektif seperti hak asal-usul dalam mempertahankan nilai nilai yang ada antar masyarakat desa.

Jika merujuk penghapusan desa yang terjadi karena program nasional yang strategis yaitu pembangunan waduk Jatigede di Kabupaten Sumedang (salah satu contoh) maka pemerintah sebenarnya telah mengeluarkan suatu kebijakan terkait implikasi hukum terhadap masyarakat desa yang mengalami penghapusan yakni Peraturan Presiden Nomor 56 Tahun 2017 Tentang Penanganan Dampak Sosial Kemasyarakatan dalam rangka penyediaan tanah untuk proyek strategis nasional. Dimana diantara 
H. Akhmad Dani dan Johansyah, Implikasi Penghapusan Desa Terhadap Kesejahteraan Masyarakat Desa, Halaman 118-134

pasal dalam Peraturan Presiden tersebut dijelaskan bahwa :

Kepada penduduk sebagaimana dimaksud dalam Pasal 2 ayat (1) huruf a diberikan tempat penampungan pemukiman baru berupa rumah pengganti dalam bentuk uang tunai, Uangtunai sebagaimana dimaksud pada huruf a diperuntukkan sebagai:

a. penggantian bangunan;

b. penggantian pengadaan tanah; dan

c. tunjangan kehilangan pendapatan.

Besaran nilai uang tunai sebagaimana dimaksud pada ayat (2) ditetapkan oleh Menteri Keuangan berdasarkan usulan Menteri Pekerjaan Umum dan Perumahan Rakyat berdasarkan hasil Rapat Koordinasi yang dipimpin oleh Menteri Koordinator Bidang Perekonomian.

Sedangkan dalam Pasal 4 menjelaskan bahwa:

Kepada penduduk diberikan uang santunan untuk:

a. biayapembongkaran rumah;

b. mobilisasi;

c. sewa rumah;

d. tunjangankehilangan pendapatan.

Besaran nilai uang santunan sebagaimana dimaksud pada ayat (1) ditetapkan oleh
Menteri Keuangan berdasarkan usulan Menteri Pekerjaan Umum dan Perumahan

Rakyat berdasarkan hasil Rapat Koordinasi yang dipimpin oleh Menteri Koordinator

Bidang Perekonomian.

Secara keseluruhan maknapasal diatas memuat terkait penggantian pengadaan tanah, mobilisasi, sewa rumah, serta tunjangan kehilangan pendapatan.

Menurut peneliti, materi muatan yang terdapat dalam perpres tersebut hanya mengatur tentang penanganan terhadap masyarakat desa secara personal yakni pemberian uang tunai untuk penggantian; bangunan, pengadaan tanah serta tunjangan hasil darikehilangan pekerjaan. Dengan demikian, hak asal usul yang menjadi hak masyarakat desa untuk mempertahankan nilai-nilai yang ada di masyarakat sehingga tidak terakomodir dalam meteri muatan Perpres tersebut. mengenaiHak asal-usul sebagaimana tercantumdalam Pasal 19 huruf (a) Undang-Undang Desa mencakup pengertian hak-hak asli masyarakatdesa yang telah ada sebelum lahir negara kesatuan republik Indonesia dan tetap hidup dan dihargaioleh masyarakatdesa setelah lahir NKRI sampai sekarang. 
H. Akhmad Dani dan Johansyah, Implikasi Penghapusan Desa Terhadap Kesejahteraan Masyarakat Desa, Halaman 118-134

Disamping itu hak-hak asli yang muncul dari prakarsa desa yang bersangkutan maupun prakarsa masyarakat setempat, sepanjang tidak bertentangan dengan ketentuan peraturan perundang-undangan yang berlaku. Dalam realitasnya, salah satu desa yang mengalami penghapusan yakni Desa Cipaku Kab. Sumedang terdapat beberapa situs leluhur yang telah mendapat perlindungan hukum, serta menjadi warisan leluhur bagi masyarakat desa untuk menjaga nilainilai antara masyarakat desa dan keyakinan-keyakinan yang tumbuh dimasyarakat desa. Akan tetapi karena menjadi salah satu desa yang dihapuskan maka keseluruhan hak kolektif tersebut terabaikan demi program nasional yang strategis yaitu pembangunan waduk.

Harmayli Ibrahim menjelaskan bahwa frasa "memandang dan mengingati" itu berarti "menghormati" atau dengan kata lain "tidak mengabaikan". Jadi konsekuensi dari jaminan yang diberikan oleh UUD NRI Tahun 1945 adalah setiap aturan negara atau peraturan perundang-undangan mengenai "daerah yang bersifat istimewa" itu haruslah tidak mengabaikan hak asal-usul daerah tersebut. Selanjutnya beliau menjelaskan bahwa pengakuan terhadap eksistensi desa tidak hanya bersifat sosiologsi, tetapi juga diakui keberadaannya sebagai subyek hukum penyandang hak dan kewajiban.

Kusnardi 5 juga berpendapat bahwa menjadi kewajiban bagi Negara Republik Indonesia untuk memelihara, menyuburkan, dan meningkatkan hal ikhwal pedesaan. Dan menjadi tidak perlu diindahkan apa yang dipesankan oleh para penyusun UUD NRI Tahun 1945 melalui penjelasan Pasal 18, agar Negara Republik Indonesia menghormati kedudukan daerah-daerah istimewa tersebut dan segala peraturan negara yang mengenai daera-daerah itu akan mengingat hak hak asal-usul daerah tersebut.

Dalam UUD NRI Tahun 1945 mengakui kenyataan historis, bahwa daerah-daerah istimewa itu telah memiliki berbagi hak dan wewenang dalam penyelenggaraan berbagai urusan pemerintahan di daerahnya. Hak-hak itu berupa hak yang dimiliki berdasarkan pemberian dari pemerintah dan hak yang telah dimilikinya sejak

5 Moh. Kusnardi dan Harmaily Ibrahim, Pengantar Hukum Tata Negara Indonesia (Jakarta: Pusat Studi Hukum Tata Negara Fakultas Hukum Universitas Indonesia dan CV Sinar Bakti). 
H. Akhmad Dani dan Johansyah, Implikasi Penghapusan Desa Terhadap Kesejahteraan Masyarakat Desa, Halaman 118-134

semula (hak yang bersifat autochtoon), atau hak yang dimiliknya sejak sebelum daerah itu merupakan bagian dari negara Republik Indonesia.

Dengan adanya hak asal usul tersebut, negara harus memperhatikan dan menghormati kewenangan asalusul yang terkait dengan nomenkaltur dan institusi atau organiasi desa. Negara tidak boleh melakukan campur tangan atau mengambil alih terhadap tanah-tanah desa sebagai hak asal-usul desa. Walaupun begitu, negara tetap masih bisa melakukan pembinaan atas pengaturan dan pengelolaan serta memberikan proteksi untuk menjaga kelesetarian dan optimalisasi pemanfaatan. Hal ini karena tidak sedikit desa atau desa adat di Indonesia yang mempunyai tanah desa sebagai aset desa yang dijaga dan diwariskan secara turun temurun. Tanah desa merupakan hak asal-usul desa yang paling vital, sebab tanah merupakan aset (kekayaan) yang menjadi sumber penghidupan dan kehidupan bagi desa dan masyarakat. Oleh karena itu, negara perlu memberikan pengakuan dan penghormatan terhadap tanah sebagai hak asal-usul desa.
Agus Kusnadi ${ }^{6}$ menjelasakan bahwa sebagaimana kebijakan yang tercermin dalam Undang-undang No. 6 Tahun 2014 tentang Desa, sistem pemerintahan desa itu terkait dengan sistem pemerintahan negara sebagai suatu kesatuan sistem hukum. Desa hanya dilihat sebagai unit komunitas politik dan administrasi pemerintahan terbawah. Akibatnya, struktur pemerintahan desa tidak ubahnya bagaikan pemerintahan yang setara dengan pemerintahan daerah dengan struktur yang disesuaikan, seperti adanya fungsi eksekutif dan legislatif, pemilihan kepala desa, dan lain sebagainya. Desa dan masyarakat desa sekali lagi hanya dilihat sebagai suatu unit politik dan administrasi, sehingga aspek ekonomi dan kesejahteraan masyarakat terabaikan.

Oleh karena itu, peneliti berpendapat perlunya pemenuhan hak terhadap masyarakat desa sebagai subjek hukum khususnya hak yang bersifat kolektif seperti hak asal-usul, sehingga nilainilai masyarakat yang terjalin antar

\footnotetext{
6 Agus Kusnadi, "Perkembangan Politik Hukum Pemerintahan Desa Menurut Undang-Undang Nomor 32 Tahun 2004 tentang Pemerintahan Daerah dan UndangUndang Nomor 6 Tahun 2014 Tentang Desa," Jurnal Ilmu Hukum Padjajaran: Universitas Padjajaran Bandung, 2015.
} 
H. Akhmad Dani dan Johansyah, Implikasi Penghapusan Desa Terhadap Kesejahteraan Masyarakat Desa, Halaman 118-134

masyarakat desa dapat terjaga meskipun telah mengalami penghapusan desa.

\section{B. Implikasi hukum Terhadap Keuangan Desa}

Ketika Merujuk dari Pasal 71 ayat (1) Undang-Undang Desa, yang dimaksud keuangan desa adalah semua hak dan kewajiban desa yang dapat dinilai dengan uang serta segala sesuatu berupa uang dan barang yang berhubungan dengan pelaksanaan hak dan kewajiban desa. Jika merujuk pada beberapa peraturan perundangundangan yang mengatur tentang keuangan, yaitu UU No. 17 Tahun 2003 tentang Keuangan Negara, UU No. 1 Tahun 2004 tentang Perbendaharaan Negara dan UU No. 15 Tahun 2004 tentang Pemeriksaan Pengelolaan dan Tanggung Jawab Keuangan Negara, maka tidak ada bab yang secara khusus mengatur tentang Keuangan Desa. Pengaturan hanya sampai di tingkat kabupaten/kota dan Desa dianggap bagian dari kabupaten/kota. Oleh karena itu pengaturan tentang keuangan desa dalam Undang-Undang Desa merupakan suatu bentuk terobosan dalam melegalkan dan melegitimasi keuangan desa dalam sistem keuangan nasional.

Sedangkan ruang lingkup Pasal 71 ayat (2) menyebutkan bahwa ruang lingkup keuangan desa adalah pendapatan, belanja, pembiayaan, dan pengelolaan keuangan Desa. Pendapatan, belanja, pembiayaan merupakan ruang lingkup jika didasarkan pada obyek, sedangkan frasa "pengelolaan keuangan Desa" merujuk pada proses pengelolaan keuangan, yang terdiri dari penyusunan, pelaksanaan anggaran dan pertanggungjawaban anggaran.

Terkait terhadap Pendapatan desa merupakan salah satu ruang lingkup keuangan desa yang akan terkena implikasi hukum dari penghapusan desa. Undang-Undang Desa telah menegaskan pengakuan negara atas Desa melalui asas rekognisi dan subsidiaritas yang mengakibatkan adanya pengakuan atas kewenangan berdasarkan hak asal usul dan kewenangan skala lokal desa. Pemberian kewenangan diikuti dengan penyerahan sumber daya kepada Desa sehingga kewenangan yang dimiliki dapat terlaksana secara maksimal. Atas dasar inilah Desa memiliki sumber- 
H. Akhmad Dani dan Johansyah, Implikasi Penghapusan Desa Terhadap Kesejahteraan Masyarakat Desa, Halaman 118-134

sumber pendapatan asli desa sebagai hak desa.

Berdasarkan Permendagri Nomor 73 Tahun 2020 Tentang Pengelolaan Keuangan Desa yang merupakan penjabaran lebih lanjut terkait keuangan desa dalam Undang Undang Desa, maka pendapatan asli desa terdiri atas beberapa bagian yaitu: Hasil Usaha;Hasil aset; Swadaya, partisipasi dan Gotong Royong; dan Lain-lain pendapatan asli desa.

Hasil usaha antara lain BUM Desa, tanah kas desa. Hasil aset antara lain tambatan perahu, pasar desa, tempat permandian umum, jaringan irigasi. Swadaya, partsipasi, dan gotong royong adalah tekait membangun dengan kekuatan sendiri yang melibatkan peran serta masyarakat berupa tenaga, barang yang dinilai dengan uang. Sedangkan terkait lain lain pendapatan asli desa antara lain hasil pungutan desa.

Dari keseluruhan bagian pendapatan asli desa maka implikasi hukum yang ditimbulkan dari penghapusan desa yakni berimplikasi terhadap keuangan desa khususnya hasil usaha desa, hasil dari pendapatan asli desa yang memuat hasil usaha, swadaya, partisipasi, gotong royong, serta pendapatan asli desa yang lain seperti hasil pemungutan desa. Dimana peraturan perundang-undangan terkait penghapusan desa tidak mengatur pengelolaan lebih lanjut terhadap keuangan desa yang mengalami penghapusan sehingga menimbulkan ketidakpastian hukum serta berpotensi merugikan desa yang telah mengalami penghapusan.

\section{Impliksi hukum Terhadap}

\section{Badan Usaha Milik Desa}

Selain itu juga Terdapat suatu ketidakpastian hukum dalam pengaturan pengelolaan BUM Desa setelah desa mengalami penghapusan, hal tersebut telah tercermin dalam beberapa peraturan perundangundangan yang mengatur terkait BUM Desa. Jika merujuk dari Peraturan Menteri Desa, Pembangunan Daerah Tertinggal, dan Transmigrasi Nomor 4 Tahun 2015 Tentang Pendirian, Pengurusan dan Pengelolaan, dan Pembubaran Badan Usaha Milik Desa, hanya terdapat pembubaran BUM Desa karena dinyatakan pailit sedangkan tidak terdapat pengaturan pengelolaan BUM Desa setelah adanya penghapusan desa. Begitu pula dengan 
H. Akhmad Dani dan Johansyah, Implikasi Penghapusan Desa Terhadap Kesejahteraan Masyarakat Desa, Halaman 118-134

Peraturan Menteri Dalam Negeri

Nomor 73 tahun 2020 Tentang

Pengelolaan Keuangan Desa tidak terdapat pengaturan pengelolaan keuangan BUM Desa setelah mengalami penghapusan.

Olehnya itu, terkait implikasi hukum yang ditimbulkan penghapusan desa terhadap BUM Desa adalah tidak tersedianya payung hukum terkait pengaturan lebih lanjut terkait pengelolaan keuangan BUM Desa setelah desa mengalami penghapusan. Tidak tersedianya payung hukum tersebut, melahirkan diskresi yang relatif luas bagi pihak yang berwenang serta berpotensi dimanfaatkan untuk kepentingan pribadi yang pada akhirnya akan merugikan masyarakat desa yang telah mengalami penghapusan.

Menurut pendapat Anang Prihantoro yang menjelaskan terkait keuangan desa selaku perwakilan dari DPD RI dalam Raker RUU Desa pada taanggal 4 April 2012 bahwa "Desa sebagai negara kecil, yang memiliki pemerintahan yang kuat sekaligus masyarakat yang kuat. Sebagai negara kecil, desa mempunyai beberapa makna penting:
Desa sebagai negara kecil bukan hanya sekedar obyek penerima bantuan pemerintah, tetapi sebagai subyek yang mampu melakukan emansipasi lokal (atau otonomi dari dalam dan otonomi dari bawah) untuk mengembangkan aset-aset lokal sebagai smber penghidupan bersama.

Desa memiliki property right atau mempunyai aset dan akses terhadap sumberdaya

lokal yang dimanfaatkan secara kolektif untuk kemakmuran bersama.

Desa bermartabat secara budaya, yang memiliki identitas atau sistem sosialbudaya yang kuat, atau memiliki kaerifan lokal yang kuat untuk mengelola masyarakat dan sumber daya lokal.'

BUMDesa jika dilihat dari fungsinya merupakan pilar kegiatan ekonomi di desa yang berfungsi sebagai lembaga sosial (social institution) dan komersial (commercialinstitution). BUM Desa sebagai lembaga sosial berpihak kepada kepentingan masyarakat melalui kontribusinya dalam penyediaan pelayanan sosial. Sedangkan sebagai lembaga komersial bertujuan mencari keuntungan melalui 
H. Akhmad Dani dan Johansyah, Implikasi Penghapusan Desa Terhadap Kesejahteraan Masyarakat Desa, Halaman 118-134

penawaran sumberdaya lokal. BUM Desa sebagai badan hukum, dibentuk berdasarkan tata perundang-undangan yang berlaku dan sesuai dengan kesepakatan yang terbangun di masyarakat desa.

Pendapat Penulis, pengaturan pengelolaan BUM Desa setelah desa mengalami penghapusan haruslah mencerminkan fungsi dari BUM Desa sebagaimana yang telah dikemukakan diatas. Yaitu memfokuskan pengelolaannya yang berpihak kepada kepentingan masyarakat desa secara adil dan merata.

\section{B. Mekanisme dalam Penghapusan Desa Berdasarkan Peraturan Perundang-Undangan yang Berlaku}

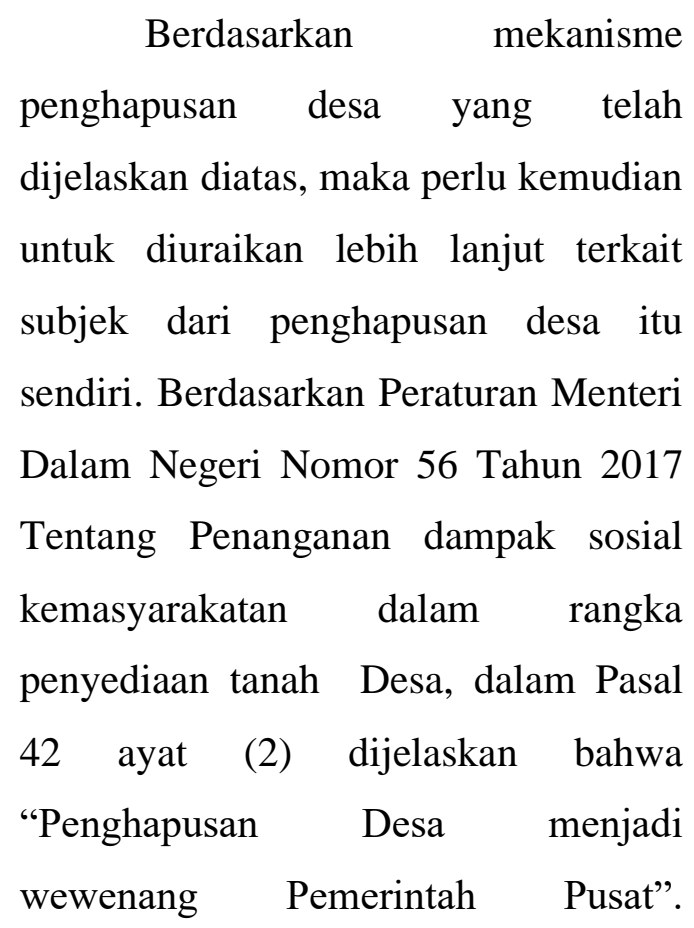

Pemerintah pusat dalam hal ini yang dimaksud adalah Presiden Republik Indonesia yang memegang kekuasaan pemerintahan Negara Republik Indonesia yang dibantu oleh Wakil Presiden dan Menteri. Wewenang Pemerintah Pusat sebagaimana dijelaskan diatas kemudian di delegasikan kepada Menteri Dalam Negeri dalam melakukan penghapusan desa.

Perihal Kedudukan Pemerintah sebagai subjek dari penataan Desa memberikan otoritas untuk dapat melakukan penataan desa termasuk penghapusan desa. Namun demikian, karena dalam Pasal 7 ayat (1) digunakan kata "dapat" maka otoritas tersebut tidak bersifat mutlak, tetapi bersyarat. Namun khusus dalam mekanisme penghapusan desa, syarat untuk melakukan penghapusan desa sepenuhnya berasal dari pemerintah sendiri sehingga otoritas pemerintah dalam penghapusan desa bersifat mutlak. Hal ini disebabkan karena alasan hukum penghapusan desa yang juga menjadi syarat utama dalam penghapusan desa yakni program nasional yag strategis merupakan kebijakan dari pemerintah sendiri dalam hal ini pemerintah pusat. 
H. Akhmad Dani dan Johansyah, Implikasi Penghapusan Desa Terhadap Kesejahteraan Masyarakat Desa, Halaman 118-134

Sementara itu, kedudukan desa dalam penghapusan desa terdapat dalam hasil musyawarah desa yang terkait penataan desa. Musyawarah desa merupakan forum permusyawaratan yang diikuti oleh Badan Permusyawaratan Desa, Pemerintah Desa, dan unsur masyarakat desa untuk memusyawarahkan hal yang bersifat strategis dalam penyelenggaraan Pemerintahan Desa. Hasil musyawarah desa terkait penataan desa hanya memberikan pertimbangan dan masukan kepada Pemerintah Daerah Kabupaten/Kota. Peran desa dalam proses penghapusan desa semakin dipersempit ketika musyawarah desa baru dilakukan setelah keluarnya Keputusan Menteri komendasi penghapusan desa oleh Menteri Dalam Negeri untuk penyusunan Rancangan Peraturan Daerah, dimana dalam Rancangan Peraturan Daerah tersebut disertai berita acara musyawarah desa.

Mekanisme Penghapusan Desa, peran desa terkait tidak dilibatkan atau tidak diberi ruang dalam memberikan pertimbangan kepada pemerintah terkait penghapusan desa. Desa baru dilibatkan untuk mengadakan musyawarah desa ketika keluarnya Keputusan Menteri Tentang
Rekomendasi Penghapusan Desa. Dengan kata lain, kedudukan desa dalam penghapusan desa adalah sebagai objek dari penghapusan desa itu.

Keterlibatan pemerintah dan Pemerintah desa dalam proses penghapusan desa yang telah dijelaskan diatas, peneliti mengganggap terdapat suatu ketidakadilan terhadap desa yang mengalami penghapusan. Dimana kewenangan penghapusan desa terletak pada pemerintah pusat sepenuhnya sedangkan peran desa dalam penghapusan desa itu sendiri telah direduksi. Oleh karena itu, kedudukan dan keberlangsungan desa pada Undang-Undang Nomor 6 Tahun 2014 Tentang Desa masih sangat bergantung pada political will satuan pemerintahan atasan desa.

Menurut Soetardjo Kartohadikoesoemo, yang memberikan pendapat bahwa; yang berhak untuk mengambil inisiatif dalam penggabungan atau pemecahan Desa adalah; (1) Pamong Praja; (2) Pemerintah daerah Kabupaten; atau (3) Rakyat Desa bersangkutan.”

Keberadaan masyarakat desa yang merupakan salah satu pihak yang mengambil inisiatif dalam penataan 
H. Akhmad Dani dan Johansyah, Implikasi Penghapusan Desa Terhadap Kesejahteraan Masyarakat Desa, Halaman 118-134

desa sebagaimana yang dikemukakan oleh Soetardjo Kartohadikoesoemo sejalan pula dengan beberapa pengaturan penghapusan desa sebelum Undang-Undang Desa seperti UndangUndang Nomor 22 Tahun 1999 Tentang Pemerintahan Daerah, dalam Pasal 93 ayat (1) dijelaskan bahwa: Desa dapat dibentuk, dihapus, dan/atau digabung dengan memperhatikan asalusulnya atas prakarsa masyarakat dengan persetujuan Pemerintah Kabupaten dan DPRD.

Berbagai pendapat serta rumusan pasal undang-undang diatas dapat memperlihatkan bahwa keterlibatan masyarakat desa yang merupakan representasi dari desa yang dihapus dalam mekanisme penghapusan desa menjadikan desa memiliki peran yang fundamental. Menurut penulis terdapat beberapa sebab masyarakat desa seharusnya memiliki peran dalam penghapusan desa. Pertama, masyarakat desa yang akan mengalami penghapusan desa merupakan pihak yang akan mengalami dampak secara signifikan setelah dilakukannya penghapusan desa. Kedua, masyarakat desa telah menjadikan desa tidak hanya sebagai tempat bermukim tapi telah menjadi unsur pemersatu dalam menjaga segala bentuk warisan leluhur yang telah ada secara turun temurun dalam suatu desa.

Sehingga Dengan merefleksikan alasan diatas, semakin menguatkan untuk melibatkan masyarakat desa dalam penghapusan desa itu sendiri yang tidak hanya bergantung dari political will dari satuan pemerintah diatas desa. Sehingga penulis berpendapat bahwa alasan penghapusan desa haruslah memperhatikan prakarsa masyarakat desa, hal ini dimaksudkan untuk menciptakan adanya proporsionalitas dan demokratisasi antara pemerintah dengan masyarakat desa.

\section{KESIMPULAN}

Implikasi hukum Dalam Penghapusan desa, telah melahirkan dampak hukum yang tidak berkesusaian dengan nilai kepastian, keadilan, serta kebergunaan yang hendak dicapai dalam tujuan penataan desa. Hal tersebut tercermin dalam pengelolaan keuangan desa dan Badan Usaha Milik Desa yang mengalami kekosongan hukum setelah penghapusan desa serta tidak terpenuhinya hak masyarakat desa subyek hukum penyandang hak 
H. Akhmad Dani dan Johansyah, Implikasi Penghapusan Desa Terhadap Kesejahteraan Masyarakat Desa, Halaman 118-134

khususnya hak kolektif yang telah dijamin dalam Undang-Undang Dasar Negara Republik Indonesia.

Acuan didalam Penghapusan desa sudah diatur dalam penataan desa sebagaimana dimuat didalam UndangUndang Nomor 6 Tahun 2014 Tentang Desa. Perihal tersebut juga Terdapat klausul tujuan penataan desa yang menjadi suatu kaedah hukum yang seharusnya dilakukan (das sollen) akan tetapi terdapat ketidaksesuain ketika kaedah hukum tersebut dihadapkan dengan penghapusan desa (das sein) karena penghapusan desa telah menafikkan seluruh ketentuan tujuan penataan desa, sehingga desa yang mengalami penghapusan yang pada akhirnya tidak berorientasi pada tujuan penataan desa tersebut. Disisi lain, alasan hukum penghapusan desa yang bersifat subjektif menjadikan peran desa dalam penghapusan desa tereduksi oleh peraturan yang berlaku.

\section{DAFTAR PUSTAKA}

Agus Kusnadi, "Perkembangan Politik Hukum Pemerintahan Desa Menurut Undang-Undang Nomor 32 Tahun 2004 tentang Pemerintahan Daerah dan Undang-Undang Nomor 6 Tahun
2014 Tentang Desa," Jurnal Ilmu Hukum Padjajaran: Universitas Padjajaran Bandung, 2015.

Ni'Matul Huda, Hukum Pemerintahan Desa, Setara Press: Malang, 2015. Moh. Kusnardi dan Harmaily Ibrahim, Pengantar Hukum Tata Negara Indonesia, Jakarta: Pusat Studi Hukum Tata Negara Fakultas Hukum Universitas Indonesia dan CV Sinar Bakti.

Muhammad Yasin Undang-Undang Nomor 6 Tahun 2014 Tentang Desa, Jakarta: Pusat Telaah dan Informasi Regional, 2015.

Rico Hermawan, Jurnal Desentralisasi Volume 17 Nomor 1, Pusat Kajian Desentralisasi dan Otonomi Daerah Lembaga Administrasi Negara, Jakarta, 2017.

Yudi Latif, Negara Paripurna, Jakarta: Kompas Gramedia, 2017. 